DOI https://doi.org/10.15589/znp2021.4(487).4

УДК 621.311 .4

\title{
DEVELOPING THE MATHEMATICAL MODEL OF SOLAR PHOTOVOLTAIC INSTALLATION
}

\section{РОЗРОБКА МАТЕМАТИЧНОЇ МОДЕЛІ СОНЯЧНОЇ ФОТОЕЛЕКТРИЧНОЇ УСТАНОВКИ}

Ihor D. Garasymchuk igorgarasymchuk@gmail.com ORCID: 0000-0002-4304-4447

Pavel V. Potapskyj

ORCID: 0000-0003-4792-8992

Ruslana V. Semenyshena

ruslanas@i.ua

ORCID: 0000-0002-2969-3635

Mykola V. Vusatiy

0611142015vus@gmail.com

ORCID: 0000-0003-3070-9283

Olexander V. Kozak

oceanalexx@gmail.com

ORCID: 0000-0002-0919-0344

\section{I. Д. Гарасимчук,} канд. техн. наук, доцент

П. В. Потапський, канд. техн. наук, доцент

Р. В. Семенишена, канд. пед. наук, доцент

М. В. Вусатий, О. В. Козак канд. техн. наук, доцент

Higher Educational Institution "Podillia State University", Kamianets-Podilskyi Заклад вищої освіти “Подільський державний університет”, м. Кам'янець-Подільський

\begin{abstract}
The present study considers the world experience and the implementation of main decisions in the sphere of effective design of autonomous solar photovoltaic installation.

The paper considers three variants of spatial orientation of a solar photovoltaic installation, which are widely used in the operation of these installations: solar photovoltaic installation with constant orientation; solar photovoltaic installation with azimuth orientation and solar photovoltaic installation with full orientation to the Sun.

On the basis of the accepted research methodology, a mathematical model of a solar photovoltaic installation was developed to determine the energy characteristics of a solar photovoltaic installation with its spatial orientation, which ensures automatic orientation to the Sun by harmonization of the production mode and the level of concession of solar radiation.

Indicators that take into account the complex effect of solar radiation intensity, air temperature, wind speed, temporal, geographical and climatic factors, measures of orientation of the solar photovoltaic system on the Sun depending on the season and day, technical and design parameters to clarify the current-voltage characteristics of solar photovoltaic installation with its spatial orientation.

The following assumptions are accepted in the developed mathematical model: the magnitude of the photocurrent is proportional to the intensity of solar radiation and does not depend on temperature; the distribution of solar radiation on the surface of solar photovoltaic batteries is uniform; the temperature for the entire volume of solar photovoltaic batteries is the same; the value of wind speed for the front and rear surfaces of solar photovoltaic batteries is the same. Dependences of output voltage and current of solar photovoltaic installation on constructive, technological parameters of solar photovoltaic elements, solar photovoltaic batteries and external factors influencing work of solar photovoltaic installation are established.

The impact of spatial orientation on the operation of a solar photovoltaic installation, taking into account complex influencing factors, has been established. The use of azimuth orientation to the Sun allows you to increase the production of solar photovoltaic installation by an average of $28 \%$, and full orientation by $40 \%$, compared with the constant orientation.
\end{abstract}

Key words: solar photovoltaic installation; spatial orientation; solar radation; heat exchange; current density. 


\section{ЕЛЕКТРОЕНЕРГЕТИКА, ЕЛЕКТРОТЕХНІКА ТА ЕЛЕКТРОМЕХАНІКА № 4ロ 2021}

Анотація. У процесі дослідження розглянуто світовий досвід і взяті до реалізації основні рішення у сфері ефективного проєктування автономної сонячної фотоелектричної установки.

У роботі розглянуто три варіанти просторової орієнтації сонячної фотоелектричної установки, які знайшли широке застосування в експлуатації цих установок, як-от сонячна фотоелектрична установка 3 незмінною орієнтацією, сонячна фотоелектрична установка з азимутною орієнтацією та сонячна фотоелектрична установка з повною орієнтацією на Сонце.

На основі методики дослідження розроблено математичну модель сонячної фотоелектричної установки для визначення енергетичних характеристик сонячної фотоелектричної установки при іiї просторовій орієнтації, що забезпечує автоматичну орієнтацію на Сонце через узгодження режиму вироблення і рівня надходження сонячної радіації.

Визначено показники, що враховують комплексну дію інтенсивності сонячного випромінювання, температури повітря, швидкості вітру, тимчасові, географічні і кліматичні чинники, міри орієнтації сонячної фотоелектричної установки на Сонці залежно від пори року і доби, технічні і конструктивні параметри установки для уточнення вольт-амперної характеристики сонячної фотоелектричної установки при ії просторовій орієнтації.

У розробленій математичній моделі прийнято такі допущення: величина фотоструму пропорційна інтенсивності сонячного випромінювання і не залежить від температури; розподіл сонячного випромінювання на поверхні сонячних фотоелектричних батарей рівномірний; температура за всім обсягом сонячних фотоелектричних батарей однакова; значення швидкості вітру для лицьової і тильної поверхні сонячних фотоелектричних батарей однакове.

Установлено залежності вихідної напруги і струму сонячної фотоелектричної установки від конструктивних, технологічних параметрів сонячних фотоелектричних елементів, сонячних фотоелектричних батарей $\mathrm{i}$ зовнішніх факторів, що впливають на роботу сонячної фотоелектричної установки.

Установлено вплив просторової орієнтації на роботу сонячної фотоелектричної установки з урахуванням чинників, які комплексно впливають. Використання азимутної орієнтації на Сонце дозволяє збільшити вироблення сонячної фотоелектричної установки в середньому на $28 \%$, а повної орієнтації - на $40 \%$ (порівняно 3 незмінною орієнтацією).

Ключові слова: сонячна фотоелектрична установка; фотоелектрична установка; просторова орієнтація; сонячне випромінювання; теплообмін; щільність струму.

\section{ПОСТАНОВКА ПРОБЛЕМИ}

Сільськогосподарський сектор економіки України $\epsilon$ одним зі значних споживачів енергоресурсів. Для сталого розвитку сільськогосподарського виробництва, особливо в умовах прискореного імпортозаміщення, електропостачання сільськогосподарських споживачів $є$ одним із пріоритетних завдань.

Особливості електропостачання сільськогосподарських споживачів, пов'язані з великою протяжністю електричних мереж, при переважно малій потужності електроустановок, сезонному характеру навантаження, а також нетривалості використання встановленої потужності викликають значні втрати електроенергії і збільшують витрати на ії передання. Крім того, через великий знос електромереж існує проблема із забезпечення надійності електропостачання цих споживачів. Усе це веде до зниження ефективності виробництва сільськогосподарської продукції. Одним зі способів вирішення проблем електропостачання сільськогосподарських споживачів $€$ застосування розподіленої генерації на основі поновлюваних джерел енергії (далі - ПДЕ). Також потрібно зазначити, що в перспективах розвитку електроенергетики України, пов'язаних зі створенням інтелектуальної активно-адаптивної мережі і місцевих мікромереж, збільшенню масштабів використання ПДЕ, зокрема енергії Сонця, приділяється особлива увага.

Незважаючи на переваги сонячної енергії, іії практичне використання як джерела електричної енергії в Україні ще не отримало помітного поширення. До перешкод активного впровадження сонячних фотоелектричних установок (далі - СФУ) належить висока вартість і низький ККД сонячних фотоелектричних елементів (далі СФЕ), нестабільність виробленої ними електричної енергії, пов'язаної з просторово-часовою мінливістю вступу сонячної радіації, іï розсіяністю, низькою щільністю. Відомим способом підвищення ефективності СФУ за допомогою максимального використання сонячної енергії, що надходить, є використання систем стеження, які дозволяють змінювати іiі просторову оріснтацію щодо Сонця. Проте вплив просторової орієнтації СФУ на ефективність іiі роботи з урахуванням тимчасових, географічних і кліматичних чинників досліджено недостатньо. Підвищення ефективності СФУ через обгрунтування іiі просторової оріснтації з урахуванням комплексних чинників $€$ актуальним завданням.

\section{АНАЛІЗ ОСТАННІХ ДОСЛІДЖЕНЬ ТА ПУБЛІКАЦІЙ}

Проєктуючи і досліджуючи СФУ, необхідно враховувати вплив різних чинників на енергетичні харак- 
теристики цих установок. Існують фізичні моделі СФЕ, що дозволяють досліджувати основні процеси, які відбуваються під час перетворення світла в електричну енергію, і різні фізичні характеристики СФЕ $[2 ; 7 ; 8]$. Такі моделі використовують для поглибленого вивчення й аналізу властивостей окремих СФЕ, вони зовсім не придатні для імітації роботи СФУ [8].

$€$ безліч аналітичних моделей СФУ, побудованих на базі еквівалентної моделі СФЕ [9]. У роботі [10] розглянуто низку аналітичних моделей СФЕ і СФБ. У [11] наведено опис різних моделей СФЕ і СФБ, проаналізовано умови їх застосування і точність моделювання ВАХ.

У роботах $[12 ; 13 ; 14]$ у математичних моделях СФБ введено обмеження за мінімальним рівнем інтенсивності сонячного випромінювання, що падає на поверхню СФЕ, і не враховано вплив робочої температури СФЕ на параметри моделі. У роботі [15] запропоновано спрощений спосіб імітаційного моделювання СФУ.

Аналіз праць, пов'язаних із моделюванням роботи СФУ, виявив необхідність розробки моделі СФУ з урахуванням чинників, які впливають на ії характеристики, що дозволяє усунути окреслені недоліки дійсних моделей і коректно визначити вихідні енергетичні характеристики СФУ, максимально наближені до реальних.

\section{МЕТА ДОСЛІДЖЕННЯ}

Підвищення ефективності вироблення електричної енергії автономних СФУ для електропостачання сільськогосподарських споживачів через створення математичної моделі для обгрунтування просторової орієнтації СФУ на основі комплексного обліку тимчасових, географічних, кліматичних чинників, технічних і конструктивних параметрів установки.

\section{МЕТОДИ, ОБ'СКТ ТА ПРЕДМЕТ ДОСЛІДЖЕННЯ}

У дослідженні використовувалися методи математичного і віртуального моделювання із застосуванням програмного забезпечення, методи розробки алгоритмів програмування, метод наземних метеорологічних вимірів і спостережень, метод «світлового еквівалента».

Об'єктом дослідження є процес вироблення електричної енергії автономною сонячною фотоелектричною установкою на базі кремнієвої сонячної фотоелектричної батареї за умов різної просторової орієнтації сонячної фотоелектричної установки.

Предметом дослідження є моделі сонячної фотоелектричної установки з її просторовою орієнтацією 3 урахуванням тимчасових, географічних і кліматичних чинників.

\section{ОСНОВНИЙ МАТЕРІАЛ}

Основним складником СФУ є СФБ, зібрані із СФЕ $з$ p-n переходом. Еквівалентна схема реального СФЕ 3 p-n переходом представлена на рис. 1.

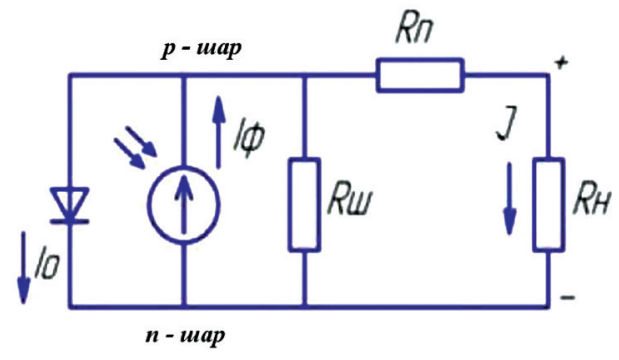

Рис. 1. Еквівалентна схема реального СФЕ

Еквівалентна схема реального СФЕ, на відміну від ідеального, враховує послідовне Rn i паралельний (шунтувальний) Rm опір СФЕ. Послідовний опір містить опір самого напівпровідникового матеріалу, 3 якого виготовлений СФЕ, перехідний опір напівпровідник - метал, опір контактів. Шунтувальний опір утворюється за рахунок наявності зворотного опору p-n-переходу, різних плівок, які проводять, або забруднень [1].

Оскільки величина шунтувального опору (ЯШ) кремнієвого СФЕ досить велика, струмовими втратами, пов'язаними з ним, можна знехтувати $[1 ; 2]$. Тому в основу математичного моделювання покладена класична модель СФЕ з p-n-переходом, що дозволяє визначити залежність напруги $U$ від щільності струму $\mathrm{J} \mathrm{A} / \mathrm{cm}^{2}$, наявності шунтувального опору і струмових втрат на ньому, які не враховуються $[1 ; 3]$ :

$$
U=\frac{A \cdot k \cdot T}{q} \cdot \ln \left[\frac{\left(J_{\Phi}-J\right.}{J_{o}}+1\right]-J R_{\Pi},
$$

де $\mathrm{A}$ - безрозмірний параметр кривизни ВАХ: $\mathrm{A}=1 \ldots 2[68] ; \mathrm{A}=1 \ldots 3[1]$;

$\mathrm{A}=1 \ldots 5[4]$.

$\mathrm{k}$ - постійна Больцмана, Дж/К;

q - заряд електрона, Кл;

Т - температура СФЕ, К;

$\mathrm{J}_{\Phi}$ - щільність фотоструму, пропорційного інтенсивності сонячного випромінювання I, що падає на поверхню СФЕ;

Јо - щільність зворотного струму насичення, А/ $\mathrm{cm}^{2}$; $\mathrm{R}$ - внутрішній електричний опір (послідовний опір), $\mathrm{OM} \cdot \mathrm{CM}^{2}$;

У роботі [5] зазначено, що в класичній моделі СФЕ, незважаючи на прийняття параметрів A, Rп константами, отримані залежності досить коректні, що повністю відбивають загальну динаміку цих характеристик зі зміною рівня освітленості.

Як було зазначено, СФБ (СФУ) складається 3 комбінації послідовно-паралельно сполучених між собою СФЕ залежно від необхідних вихідних параметрів (напруги, струму, потужності СФУ), визначаються виходячи з таких співвідношень:

$$
U_{C \Phi У}=U_{C \Phi E} \cdot N_{\text {ПС }},
$$




\section{ЕЛЕКТРОЕНЕРГЕТИКА, ЕЛЕКТРОТЕХНІКА ТА ЕЛЕКТРОМЕХАНІКА № 4 - 2021}

$$
J_{C \Phi y}=J \cdot S_{C \Phi E} \cdot N_{\Pi P},
$$

де $\mathrm{U}_{\mathrm{CФЕ}}-$ напруга СФЕ, $\mathrm{B}$;

$\mathrm{N}_{\text {пр }}$ - число паралельно сполучених елементів, шт.;

$\mathrm{N}_{\text {пс }}$ - число послідовно сполучених елементів, шт.;

$\mathrm{S}_{\mathrm{CФЕ}}-$ площа СФЕ, см$^{2}$.

Для розрахунків потрібна низка початкових даних, як-от $\mathrm{J}_{\Phi}, \mathrm{J}_{\mathrm{o}}, \mathrm{U}_{\mathrm{xx}}$. Як правило, значень цих величин отримують із паспортних даних. Проте в реальних умовах роботи СФУ вказані характеристики мінливі, зважаючи на зміни параметрів зовнішнього середовища. Вплив зміни щільності потоку сонячного випромінювання і робочої температури на ВАХ СФЕ детально розглянуто в роботі [4]. У статті наведено загальні аналітичні залежності зміни значень струму і напруги від щільності потоку сонячного випромінювання і робочої температури для космічних і наземних СФБ.

Спростивши низку формул, наведених у [4], враховуючи те, що в розрахунках використовуватимуться паспортні значення основних параметрів СФЕ, отримані за стандартних умов випробувань, для наземних СФУ вплив зміни інтенсивності сонячного випромінювання і робочої температури на ВАХ СФЕ можна записати у вигляді виразів:

$$
\begin{gathered}
J_{K .3 .}=J o_{K .3 .}+\Delta J_{I}+\Delta J_{T}, \\
U_{X . X .}=U o_{X . X .}+\Delta U_{I 1}+\Delta U_{I 2}+\Delta U_{T},
\end{gathered}
$$

де $J o_{K, 3}$ i $U o_{X X}$ - початкові значення щільності струму короткого замикання і напруги холостого ходу, виміряні за стандартних умов освітлення AM1 $\left(\mathrm{I}_{0}=1000 \mathrm{BT} / \mathrm{M}^{2}\right)$ і температури СФЕ $\left(\mathrm{T}_{0}=(25+2)^{\circ} \mathrm{C}\right)[31]$; $\Delta J_{I}, \Delta U_{I 1}, \Delta U_{I 2}-$ поправки, які враховують зміну щільності потоку сонячного випромінювання;

$\Delta J_{T}, \Delta U_{T}-$ поправки, які враховують зміну температури СФЕ.

3 низки параметрів зовнішнього довкілля на енергетичні характеристики СФЕ, зокрема СФУ, значно впливають інтенсивність сонячного випромінювання і температура повітря. Як зазначалося раніше, інтенсивність сонячного випромінювання безпосередньо впливає на фотострум СФЕ, а температура довкілля - на температуру СФЕ, значне збільшення якої зменшує вихідну потужність унаслідок лінійного падіння напруги холостого ходу. 3 огляду на це, у процесі проєктування і дослідження СФУ виникає завдання визначення значень інтенсивності сонячного випромінювання і температури повітря. На значення інтенсивності сонячного випромінювання, що падає на поверхню СФБ установки, значно впливає міра її просторової орієнтації.

У роботі розглядаються три варіанти просторової орієнтації СФУ, які знайшли широке застосування в процесі експлуатації цих установок:

- СФУ 3 незмінною орієнтацією (без системи стеження за Сонцем). СФУ орієнтована на південь і встановлена до горизонту під оптимальним кутом (1 варіант - базовий);

- СФУ з азимутною орієнтацією. СФУ встановлена під оптимальним кутом до горизонту і орієнтується на Сонце за азимутом (2 варіант);

- СФУ з повною орієнтацією на Сонце (3 варіант).

Наприклад, сумарна інтенсивність сонячного випромінювання на похилу поверхню (з незмінною орієнтацією) розраховувалася за формулою [4]:

$$
I_{H}=I_{\Pi} \frac{\cos \xi}{\cos \theta}+I_{\text {म }} \frac{(1+\cos \beta)}{2}+\rho\left(I_{\Pi}+I_{\text {Д }}\right) \frac{1-\cos \beta}{2},
$$

де $I_{\Pi}, I_{д}-$ інтенсивність прямого і дифузного (розсіяного) сонячного випромінювання на горизонтально розташовану поверхню, Вт/м²;

$\theta$ - кут між напрямами на зеніт і Сонце (Рисунок 2) в град.; $\xi$ - кут між нормаллю до похилої, орієнтованої на південь поверхні і напрямом на Сонці (Рис. 2) в град.;

$\beta$ - кут нахилу поверхні до горизонту (Рис. 2) в град.; $\rho$ - коефіцієнт віддзеркалення земної поверхні (альбедо).

Для опису математичної закономірності зміни температури повітря протягом доби застосовувалася залежність [7]:

$$
T_{B}(t)=\bar{T}_{O B}+\frac{\Delta T_{M}}{2} \cos \left(\frac{2 \pi}{t_{\Pi}}\left(t_{\text {solar }}-t_{M}\right)\right),
$$

де $\bar{T}_{O B}$ - середньодобова температура повітря, ${ }^{\circ} \mathrm{C}$; $\Delta \mathrm{T}_{\mathrm{M}}$ - добова амплітуда температури повітря, ${ }^{\circ} \mathrm{C}$; $t_{\Pi}-$ період зміни температури повітря, год.;

$t_{M}$ - час настання максимального значення температури повітря за місцевим (локальним) сонячним часом, год.; $t_{\text {solar }}$ - час локальний (місцевий) сонячний у год..

Робоча температура СФЕ під час експлуатації вста-

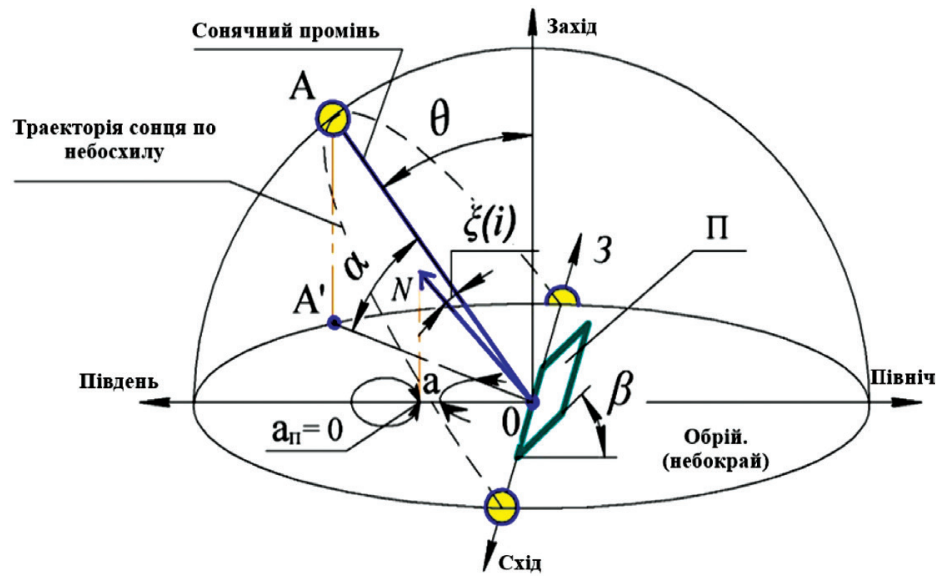

Рис. 2. Кути, що визначають просторову орієнтацію наземних СФУ щодо Сонця: Пів., Пів., Зах., Схід - сторони світу; А - місце розташування Сонця на небосхилі; а - азимут Сонця; $\theta$ - зенітний кут і $\alpha$ - кут висоти Сонця; П - робоча поверхня СФУ (СФБ); $\mathrm{N}$ - нормаль до П; $\mathrm{a}_{\mathrm{n}}-$ азимут П; $\xi(\mathrm{i})$ - кут між напрямом на Сонці (OA) i N; $\beta$ - кут нахилу П. 
новлюється за допомогою теплообміну СФБ $з$ температурою довкілля. Тепло, СФБ, що виділяється, залежить від його оптичних властивостей і захисного покриття (коефіцієнтів віддзеркалення), ККД СФЕ, щільність їх упаковки в СФБ тощо. Теплообмін між СФБ і довкіллям відбувається за допомогою кондукції, конвекції і випромінювання.

Температуру СФЕ можна визначити через рівняння енергетичного балансу СФБ за формулою [68]:

$$
T=\frac{I \cdot\left[\mu-\eta_{0} \cdot\left(1+\chi \cdot T_{0}\right)\right]+\lambda \cdot F \cdot T_{B}}{\lambda \cdot F-I \cdot \eta_{0} \cdot \chi},
$$

де $I$ - інтенсивність випромінювання на СФЕ, віднесені до одиниці поверхні СФБ $\left(\mathrm{S}_{\mathrm{CФБ}}\right), \mathrm{BT} / \mathrm{M}^{2}$;

$\mu$ - інтегральний коефіцієнт поглинання сонячного випромінювання СФБ;

$\eta_{0}-$ ККД СФЕ, отриманий за стандартних умов випробування;

$\chi$ - температурний градієнт, залежний від типу і конструкції СФБ (його значення змінюється в діапазоні $0,003 \ldots 0,005 \mathrm{~K}-1[116])$;

$T_{0}$ - температура СФЕ за стандартних умов випробування, К;

$\lambda$ - коефіцієнт тепловіддачі з поверхні СФБ, Вт/( ${ }^{2}$ К); $F$ - відношення площі плоскою СФБ (тильною і лицьовою) до площі освітлюваної поверхні;

$T_{B}$ - температура навколишнього повітря, К.

Під час розрахунку сумарної інтенсивності сонячного випромінювання враховуються кути падіння сонячних променів на приймальну поверхню при прямій сонячній радіації, кути геометричної видимості приймальної поверхні при розсіяній і дифузній радіації. Проте в СФБ неминучі втрати сонячної енергії, що приходить на її поверхню. Вони пов'язані 3 наявністю захисної поверхні. Матеріалом, із якого виготовляється захисна поверхня СФБ, здебільшого в наземній енергетиці, $є$ скло, що має високу пропускну спроможність для сонячної радіації.

Залежно від сорту і товщини скла коефіцієнт пропускання сонячної радіації при перпендикулярному падінні променів на iї поверхню перебуває в межах 0,9-0,78.

У [7] наведено значення частки відбитої енергії, що пройшла; при різних кутах падіння світла на поверхню скла $з$ цих даних видно, що при кутах падіння випромінювання від 0 до $60^{\circ}$ частка проходження сонячної енергії майже не міняється i залишається високою (коефіцієнт пропускання максимальний), тоді як при великих кутах коефіцієнт пропускання різко зменшується, збільшуючи коефіцієнт віддзеркалення. Облік втрат сонячної енергії в захисному склі СФБ, які впливають на енергетичні вихідні характеристики СФУ, дозволить найточніше наблизити теоретичні характеристики СФУ до дійсних, вироблювані СФУ в реальних умовах роботи.
3 урахуванням усіх вищенаведених та інших урахованих нами залежностей складено математичну модель СФУ в загальному вигляді, яку можна представити системою рівнянь:

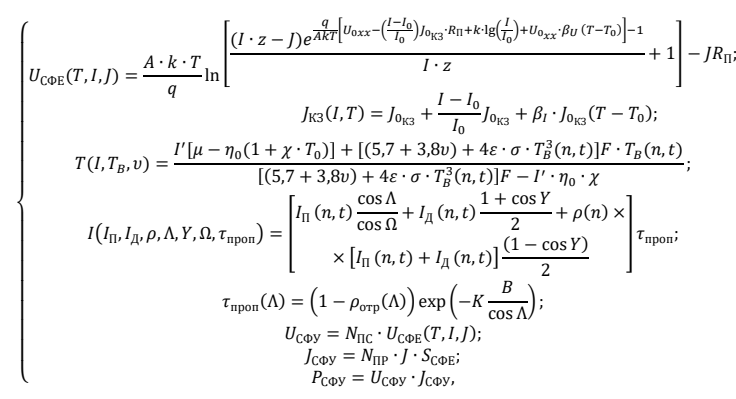

де $U_{C Ф E}-$ напруга СФЕ, B; $A$ - безрозмірний параметр кривизни ВАХ; $k$ - постійна Больцмана, Дж/К; $q$ - заряд електрона, Кл; $T$ - температура СФЕ, К; I, I' - інтенсивність сонячного випромінювання, що падає на поверхню СФЕ і належить до одиниці поверхні СФУ (СФБ), Вт/м²; z - коефіцієнт пропорційності щільності фотоструму до інтенсивності сонячного випромінювання, $\mathrm{A} \cdot \mathrm{M}^{2} / \mathrm{BT} \cdot \mathrm{cm}^{2} ; J$ - щільність струму, $\mathrm{A} / \mathrm{cm}^{2} ; U_{O X X}, J_{O K 3}-$ напруга холостого ходу (В) і щільність струму короткого замикання $\left(\mathrm{A} / \mathrm{cm}^{2}\right)$ СФЕ, виміряні за стандартних умов освітлення AM1 $\left(I_{0}=1000 \mathrm{BT} / \mathrm{M}^{2}, T_{0}=298,15 K\right) ; R_{\Pi}-$ внутрішній електричний опір (послідовне), Ом см²; $\kappa$ - безрозмірний коефіцієнт освітленості; $\beta_{I}, \beta_{U}$ - температурні коефіцієнти струму і напруги, $\mathrm{K}^{-1} ; J_{K 3}$ - щільність струму короткого замикання, $\mathrm{A} / \mathrm{cm}^{2} ; \mu$-інтегральний коефіцієнт поглинання сонячного випромінювання СФБ; $\eta_{0}$ - коефіцієнт корисної дії (далі - ККД) СФБ, отриманий за стандартних умов випробування; $X$ - температурний градієнт, залежний від типу і конструкції СФБ, $\mathrm{K}^{-1} ;(5,7+3,8 v)$ - розмірне співвідношення Мак-Адамса для розрахунку коефіцієнта конвекції, $\mathrm{BT} /\left(\mathrm{M}^{2} \mathrm{~K}\right)$, де $\mathrm{v}$ - швидкість вітру, м/с; $\varepsilon$ - інтегральний коефіцієнт випромінювання СФБ; $\sigma-$ постійна Стефана-Больцмана, Вт/( $\left.\mathrm{M}^{2} \mathrm{~K}^{4}\right) ; T_{B}$ - температура навколишнього повітря, К; $n-$ порядковий номер дня року, відлічуваний від 01 січня; $t$ - час, год.; $F$ - відношення площі плоскою СФБ (тильною і лицьовою) до площі освітлюваної поверхні; $I_{I}, I_{Д}$ - інтенсивність прямого і дифузного (розсіяного) сонячного випромінювання на горизонтальну поверхню, Вт/м²; $\Lambda, \Omega, Y$ - кути, що визначають просторову орієнтацію наземних СФУ, град.; $\rho$ - коефіцієнт віддзеркалення земної поверхні (альбедо); $\tau_{n р о n}, \rho_{\text {отр }}-$ коефіцієнти пропускання і віддзеркалення сонячного випромінювання захисною поверхнею СФБ; $K$ - показник поглинання сонячного випромінювання захисною поверхнею СФБ, см$^{-1}$; В - товщина захисної поверхні СФБ, см; $U_{C Ф У}$ - напруга СФУ, В; $J_{C Ф У}-$ струм навантаження СФУ, А; $N_{\text {ПС }}, N_{\Pi Р}$ - число послідовно і паралельно сполучених СФЕ в СФБ, В; $\mathrm{S}_{\mathrm{CФЕ}}-$ площа СФЕ, см$^{2}$; $P_{\text {СФЕ }}$ - потужність СФУ, ВТ.

Кути, що визначають просторову орієнтацію наземних СФУ (рис. 2) для розглянутих у роботі трьох варіантів по-різному орієнтованих установок рівні: 


\section{ЕЛЕКТРОЕНЕРГЕТИКА, ЕЛЕКТРОТЕХНІКА ТА ЕЛЕКТРОМЕХАНІКА № 4 - 2021}

- СФУ $з$ незмінною орієнтацією, орієнтована на південь і встановлена до горизонту під оптимальним кутом (1 варіант - базовий

$$
\Lambda=\xi, \Omega=\theta, \mathrm{Y}=\beta ;
$$

- СФУ, встановлена під оптимальним кутом (до горизонту і орієнтована (що стежить) на Сонці за азимутом (2 варіант)

$$
\Lambda=\mathrm{i}, \Omega=\theta, \mathrm{Y}=\beta ;
$$

- СФУ з повною орієнтацією (стеженням) на Сонце (3 варіант)

$$
\Lambda=\Omega=\mathrm{Y}=\theta \text {. }
$$

Як допущення в розробленій математичній моделі прийнято таке:

- послідовний опір СФЕ не залежить від інтенсивності сонячного випромінювання і температури СФЕ;

- величина фотоструму пропорційна інтенсивності сонячного випромінювання і не залежить від температури;

- спектральна чутливість СФЕ і внутрішні втрати енергії, пов'язані з можливим затінюванням СФЕ або їх частин, не враховуються;

- розподіл сонячного випромінювання на поверхні СФБ рівномірний (ураховується зміна площі видимості СФБ сонячними променями, але не враховується міра затінювання);

- температура за усім обсягом СФБ однакова, 3 відсутністю перепадів температур уздовж іiі поверхні;

- значення швидкості вітру для лицьової і тильної поверхні СФБ однакове, напрям вітру не враховується, тобто розмір поверхні СФБ, що обдувається, не змінений.

Розроблена математична модель СФУ дозволяе оцінити вплив на вихідні енергетичні характеристики СФУ, як внутрішніх, так і зовнішніх чинників (інтенсивності сонячного випромінювання, температури повітря, швидкості вітру, міри орієнтації СФУ на Сонці залежно від пори року і доби).

\section{ОБГОВОРЕННЯ ОТРИМАННЯ РЕЗУЛЬТАТІВ}

У реальних умовах експлуатації СФУ виявляються під впливом зовнішнього довкілля, яке впливає на вихідні енергетичні характеристики. Цей вплив призводить до значних відмінностей, передбачуваних теоретично розрахованих і реальних значень вихідних енергетичних характеристик.

Отже, розробка моделі має бути спрямована на рішення основних двох завдань: математичного опису процесів, що відбуваються під час роботи СФУ під впливом внутрішніх і зовнішніх чинників, i знаходження параметрів довкілля (зовнішніх чинників). 3 огляду на вищесказане, під час розробки моделі СФУ перевага віддаватиметься імітаційному моделюванню.

Тому для проведення розрахунків і візуального відображення необхідних даних і графіків на ЕОМ під час дослідження роботи СФУ, слід розроблену математичну модель СФУ реалізувати в програмному середовищі імітаційного моделювання MATLAB/Simulink.

\section{ВИСНОВКИ}

1. Встановлено залежності вихідної напруги і струму СФУ від конструктивних, технологічних параметрів СФЕ, СФБ і зовнішніх факторів, що впливають на роботу СФУ.

2. 3 урахуванням установлених залежностей розроблено математичну модель СФУ, яка дозволяє визначити іiі енергетичні характеристики на основі показників, що враховують комплексну дію інтенсивності сонячного випромінювання, температури повітря, швидкості вітру, технічних і конструктивних параметрів установки у разі зміни її просторової орієнтації.

3. Установлено вплив просторової орієнтації на роботу СФУ з урахуванням чинників, які комплексно впливають. Так, використання азимутної орієнтації на Сонці дозволяє збільшити вироблення СФУ в середньому на $28 \%$, при повній орієнтації - на $40 \%$ (порівняно з незмінною орієнтацією).

\section{REFERENCES}

[1] GOST R 51597-2000. (2000) Netradicionnaja jenergetika. Moduli solnechnye fotojelektricheskie. Tipy i osnovnye parametry. Vved. [Innovative energy. Solar photovoltaic modules. Types and basic parameters. Introduction] 2000-04-21. M. : IPK Izd-vo standartov. 8 s. [in Russian]

[2] Aronova E. S. (2010) Metodika obosnovanija parametrov sistem avtonomnogo jelektrosnabzhenija na baze solnechnyh fotojelektricheskih ustanovok: dis. kand. tehn. nauk: 05.14.08 [Methods of parameter substantiation of autonomous power supply systems based on solar photovoltaic installations: dis. of Ph. in Techn. Sciences 05.14.] / Aronova Ekaterina Sergeevna. Spb. 149 s. [in Russian].

[3] Helibajk Ch. (2007)/ Programmirovanie PIC-mikrokontrollerov na PicBasik. [ Programming of PIC-microcontrollers with the help of PicBasic]; per. s angl. M. : Dodeka XXI. 321 s. [in Russian].

[4] Harchenko N. V. (1991). Individual'nye solnechnye ustanovki [Individual solar installations]. M.: Jenergoatomizdat, S. 126-128. [in Russian].

[5] Il'inskij N. F., Moskalenko V. V. (2008). Jelektroprivod: jenergo - i resursosberezhenie: ucheb. posobie dlja stud. Vyssh. ucheb. Zavedenij [Electric drive: energy - and resource saving: manual for university students]. K. : Izd. cent "Akademija". S. 36-40. [in Russian]. 
[6] Lavrinenko Ju.M., Savchenko P.I., Synjavs'kyj O.Ju., Vojtjuk D.G., Savchenko V.V., Golodnyj I.M. (2017). Osnovy elektropryvoda: pidruchnyk [Basics of electric drive: textbook]. K. : Vydavnyctvo Lira-K. 524 s. [in Russian].

[7] VII Mizhnarodna naukovo-tehnichna konferencija "Intelektual'ni energetychni systemy. ESS 2020". [VII International Scientific and Technical Conference "Intelligent Energy Systems. ESS 2020"] 23-25 kvitnja 2020 roku, m. Kyi’v, NTUU "KPI". www.ied.org.ua,ess.ieee.org.ua. [in Ukrainian].

[8] Ulapane, N., Abeyratne S., Binduhewa P., Dhanapala C., Wickramasinghe S., Rathnayake N. A Simple Software Application for Simulating Commercially Available Solar Panels. International Journal of Resent Trends in Engeneering. 2012. Vol 2. no. 5. P. 48-66. [in English].

[9] VIII Mizhnarodna konferencija i vystavka sonjachnoi' energetyky “Sonjachna energetyka Central'noi' i Shidnoi' Jevropy CISOLAR-2020" [VIII International Conference and Exhibition of Solar Energy "Solar Energy of Central and Eastern Europe CISOLAR-2020”]. 07-09 kvitnja 2020 roku, m. Kyi’v, Hilton Kyiv, VC Akko Interneshnl. cisolar@ibcentre.org. [in Ukrainian].

[10] Harchenko V.V., Adomavichjus V. B., Gusarov V. A., Strebkov D. S. (2012) Mikroset' na osnove VIJe dlja jenergosnabzhenija sel'skih territorij [Microgrid based on renewable energy sources for energy supply of rural areas]. International conference "ENERGY OF MOLDOVA - 2012. REGIONAL ASPECTS OF DEVELOPMENT" October 4-6. Chisinau, Republic of Moldova. P. 562-567. [in Russian].

[11] GOST 28976-91. Fotojelektricheskie pribory iz kristallicheskogo kremnija. Metodika korrekcii po temperature i obluchennosti rezul'tatov izmerenija vol't-ampernoj harakteristiki. Vved. [Photovoltaic devices made of crystalline silicon. Method of correction by temperature and irradiation of the results of measuring the volt-ampere characteristic. Introduction] 1992-01-01. M. : IPK Izd-vo standartov, 2004. 7 s. [in Russian].

[12] Gliberman A. Ja., Zajceva A. K. (1961). Kremnievye solnechnye batarei [Silicon Solar Cells]. M. L. : Gosjenergoizdat, 72 s. [in Russian].

[13] Lukutin B.V., Surzhikova O.A., Shandarova E.B. (2008). Vozobnovljaemaja jenergetika v decentralizovannom jelektrosnabzhenii: monografija [Renewable energy in decentralized electricity supply : monograph]. M. : Jenergoatomizdat. 231 s. [in Russian].

[14] Petuhov O.A., Morozov A.V., Petuhova E.O. (2008). Modelirovanie: sistemnoe, imitacionnoe, analiticheskoe: ucheb. Posobie [Modeling: system, simulation, analytical: training. allowance]. 2-e izd., ispr. i dop. SPb. : Izd-vo SZTU. 288 s. [in Russian].

[15] Andreev V.M., Grilihes V.M., Rumjancev V.D. (1989). Fotojelektricheskoe preobrazovanie koncentrirovannogo solnechnogo izluchenija [Photovoltaic conversion of concentrated solar radiation]. L. : Nauka,. 310 s. [in Russian].

\section{СПИСОК ВИКОРИСТАНОЇ ЛІТЕРАТУРИ}

[1] ГОСТ Р 51597-2000. Нетрадиционная энергетика. Модули солнечные фотоэлектрические. Типы и основные параметры. Введ. 2000-04-21. Москва : ИПК Изд-во стандартов, 2000. 8 с.

[2] Аронова Е.С. Методика обоснования параметров систем автономного электроснабжения на базе солнечных фотоэлектрических установок: дис. канд. техн. наук: 05.14.08. Санкт-Петербург, 2010. 149 с.

[3] Хелибайк Ч., Программирование PIC-микроконтроллеров на PicBasik; пер. с англ. Москва : Додека XXI, 2007. 321 с.

[4] Х Харченко Н.В. Индивидуальные солнечные установки. Москва : Энергоатомиздат. 1991. С. 126-128.

[5] Ильинский Н.Ф., Москаленко В.В. Электропривод: энерго- и ресурсосбережение : учебное пособие. Киев : Изд. цент «Академия». 2008. С. 36-40.

[6] Лавріненко Ю.М., Савченко П.І., Синявський О.Ю., Войтюк Д.Г., Савченко В.В., Голодний І.М. Основи електропривода : підручник. Київ : Видавництво Ліра-К. 2017. 524 с.

[7] VII Міжнародна науково-технічна конференція «Інтелектуальні енергетичні системи. ESS 2020». 23-25 квітня 2020 року, м. Київ, НТУУ «КПІ». URL: www.ied.org.ua,ess.ieee.org.ua.

[8] Ulapane N., Abeyratne S., Binduhewa P., Dhanapala C., Wickramasinghe S., Rathnayake N. A Simple Software Application for Simulating Commercially Available Solar Panels. International Journal of Resent Trends in Engeneering. Vol 2. No. 5. 2012. P. 48-66.

[9] VIII Міжнародна конференція і виставка сонячної енергетики «Сонячна енергетика Центральної і Східної Свропи CISOLAR-2020». 07-09 квітня 2020 року, м. Київ, Hilton Kyiv, ВЦ Акко Інтернешнл. cisolar@ibcentre.org.

[10] Харченко В.В., Адомавичюс В.Б., Гусаров В.А., Стребков Д.С. Микросеть на основе ВИЭ для энергоснабжения сельских территорий. International conference "ENERGY OF MOLDOVA - 2012. REGIONAL ASPECTS OF DEVELOPMENT" October 4-6. Chisinau, Republic of Moldova. 2012. P/ 562-567.

[11] ГОСТ 28976-91. Фотоэлектрические приборы из кристаллического кремния. Методика коррекции по температуре и облученности результатов измерения вольтамперной характеристики. Введ. 1992-01-01. Москва : ИПК Изд-во стандартов, 2004. 7 с.

[12] Глиберман А.Я., Зайцева А.К. Кремниевые солнечные батареи. Москва; Ленинград : Госэнергоиздат, 1961. 72 с.

[13] Лукутин Б.В., Суржикова О.А., Шандарова Е.Б. Возобновляемая энергетика в децентрализованном электроснабжении : монография. Москва : Энергоатомиздат. 2008. $231 \mathrm{c.}$

[14] Петухов, О.А., Морозов, А.В., Петухова, Е.О. (2008). Моделирование: системное, имитационное, аналитическое : учебное пособие. 2-е изд., испр. и доп. Санкт-Петербург : Изд-во СЗТУ, 2008. 288 с.

[15] Андреев В.М., Грилихес В.М., Румянцев В.Д. Фотоэлектрическое преобразование концентрированного солнечного излучения. Ленинград : Наука. 1989. 310 с.

(C) Гарасимчук І. Д., Потапський П. В., Семенишена Р. В., Вусатий М. В., Козак О. В. Дата надходження статті до редакції: 29.11.2021 Дата затвердження статті до друку: 14.12.2021 